\title{
Factors associated with initiation of breast-feeding in the Dominican Republic ${ }^{1}$
}

\author{
Leonelo E. Bautista ${ }^{2}$
}

ABSTRACT The determinants of initiating breast-feeding vary among different populations, but knowledge of them is of fundamental importance for guiding programs to promote breast-feeding. Data from the Demographic and Health Survey of 1991 in the Dominican Republic were used to identify factors associated with the initiation of breast-feeding in a random sample of women of reproductive age. Approximately 93\% of 2714 mothers reported having begun to breast-feed their last live-born child who was currently under 5 years of age, and that percentage had not changed substantially in the past 5 years. A logistic regression analysis was done in which odds ratios $(\psi)$ were calculated as measures of association. Women who had suffered some type of illness during pregnancy $(\psi=2.3)$, those whose child had a low birthweight $(\psi=2.9)$, primiparas $(\psi=1.9)$, and those with medium $(\psi=1.6)$ or high $(\psi=2.1)$ income levels showed a significantly higher risk of not starting to breast-feed. These women should be considered priority groups by breast-feeding promotion programs.

The favorable effects of breast-feeding on child health are well known. There is an abundance of evidence showing that breast milk decreases both the incidence and severity of infectious diseases, primarily acute diarrhea $(1,2)$ and acute respiratory infections $(3,4)$. Breast-feeding is also the most appropriate form of nourishment for ensuring adequate growth and development during the first 6

\footnotetext{
This research study was conducted with financing provided by the Institute for Resource Development (IRD), Macro/International. A Spanish version of this article has previously been published in this journal (Vol. 1, No. 3, 1997, pp. 200-207) under the title "Factores asociados al inicio de la lactancia materna en mujeres dominicanas."

2 Industrial University of Santander, School of Health, Department of Public Health, Bucaramanga, Colombia. Mailing address: Universidad Industrial de Santander, Facultad de Salud, Departamento de Salud Pública, Carrera 32, Calles 29 y $30,3 e r$ piso, Bucaramanga, Colombia.
}

months of life (5). Moreover, it produces indirect health benefits for both the mother and her child by prolonging the intervals between pregnancies, decreasing fertility (6), and reducing expenditures on feeding and medical care.

The extent to which breast-feeding's beneficial effects are realized, however, depends on whether breast-feeding is initiated, its duration, and the age at which the breast-fed child is weaned $(4,7)$. It is known that breast-feeding patterns and factors influencing these patterns vary from one country to another (8-10). Hence, the study of these relationships in specific populations is of considerable importance for objectively and effectively orienting breast-feeding promotion activities and for preventing that decline in the initiation of breast-feeding that appears to occur in developing countries as a result of rapid urbanization, transacculturation, and the influence of practices by wealthier social groups upon those of poorer ones $(8,11)$.

The information available on breastfeeding in the Dominican Republic is limited. The demographic and health surveys of 1986 and $1991(12,13)$ probably constitute the most representative and recent data sources describing the situation. However, these surveys and other data sources (12-15) limit themselves to describing breast-feeding patterns. The purpose of the work reported here was to reanalyze data from the 1991 Demographic and Health Survey (Encuesta Demográfica y de Salud de 1991, ENDESA-91) (13) in an effort to determine which particular sociodemographic, medical care, pregnancy, and neonatal characteristics independently influenced the initiation of breast-feeding. 


\section{MATERIALS AND METHODS}

A cohort study was conducted using data from ENDESA-91. This survey (13) was part of the Demographic and Health Surveys Program that has been carried out in a number of countries since 1984 by the Institute for Resource Development and The Population Council with funding provided by the U.S. Agency for International Development (USAID). The ENDESA91 survey included 7142 Dominican women between the ages of 15 and 49, who constituted a study population selected by probabilistic, multi-stage, stratified cluster sampling. By means of interviews conducted with mothers, retrospective data were gathered on initiation of breast-feeding in cases where live births occurred during the 5 years preceding the survey (13).

Only pairs consisting of a mother and her last live-born child (where the child was less than 60 months old at the time of the survey) were considered eligible. The last live-born child was selected because the maternal recall period for data describing such children was shorter than the recall periods for data on children born previously. In addition, use of information on the last live-born child made it possible to generate a more current picture of breast-feeding characteristics and avoided problems relating to lack of observational independence when more than one child of a given mother is included.

In cases where the child's age as reported by the mother and the child's age as indicated by its birth date diverged by over a year, the pair was excluded from the study, it being felt that other data were likely to be unreliable. However, pairs in which the child was deceased were not excluded, since even those who died before reaching 1 month of age were likely to have been breast-fed at some time.

Factors evaluated as potential determinants for initiation of breast-feeding were placed in one of three groups: sociodemographic variables, characteristics of medical care during pregnancy and childbirth, and characteristics of the pregnancy or the child
(Table 1), using the model questionnaires of the worldwide program of demographic and health surveys (DHS Model A) $(13,16)$.

The study mothers were classified sociodemographically in terms of household income, which was estimated on the basis of major material goods found at the home. Each type of article was assigned a relative value in accordance with its market price. ${ }^{3}$

For each mother, a total score was calculated by taking the sum of all such values. The distribution terciles, corresponding to point scores of 2.0 and 7.5, were used as cutoff points for grouping participants into low-, medium-, or high-income categories. This classification was strongly associated with type of residence (urban or rural) and level of maternal education.

As a result of high levels of unemployment, job instability, and a considerable diversity of income sources, it was felt that a determination of income level based on salary or monthly income would be unreliable for this population group. Instead, the approach taken, as described above, made it possible to combine income from various sources over long periods of time and thus to better classify mothers into what were effectively income-level categories.

The percentage of study children that were never breast-fed was taken as an inverse measure of the relative frequency of breast-feeding. However, each eligible woman in the original sample did not have the same probability of being included in the study (13). Therefore, in order to obtain estimates representative of the population, the percentage of children never breast-fed was weighted by multiplying each observation by the inverse of the mother's selection probability and then combining the resulting products.

The odds ratio $(\psi)(17)$ and its $95 \%$ confidence interval (95\% CI), calculated using the Cornfield method (18), were used as a measure of association

\footnotetext{
The values assigned were: $1=$ fan, radio, or iron $1.5=$ gas stove; $2=$ hi-fi or stereo, air conditioning, television set, or refrigerator; 3 = washing machine or motorcycle; 6 = automobile.
}

TABLE 1. Factors considered as potential influences on the initiation of breastfeeding in the current study; Dominican Republic, 1991

Sociodemographic variables:

Mother's age in years completed at the time of the child's birth

Mother's formal education (highest grade completed)

Area of residence (urban or rural)

Socioeconomic level (rated according to material possessions found in the home)

Mother's number of deliveries (primipara or multipara)

Mother's employment status at the time of the child's birth

Child's age

Variables relating to medical care during pregnancy and delivery:

Number of prenatal checkups

Health personnel conducting prenatal checkups

Health personnel responsible for care during childbirth

Place where delivery took place (home, public facility, private facility)

Variables related to pregnancy and the child: Illness during pregnancy reported by the mother $^{\mathrm{a}}$

Type of delivery (cesarian section or vaginal)

Child's sex

Child's birthweight

a Risk of miscarriage, vaginal hemorrhage, placenta previa, high blood pressure, cardiopathy, diabetes, kidney disease, liver disease, tuberculosis, or tumors.

for quantifying the effect of each variable on the initiation of breast-feeding.

To calculate the adjusted effect of each variable on the initiation of breast-feeding, multiple logistic regression was employed (19). The aim of the regression model, constructed using Greenland's criteria (20), was to find the simplest equation that could describe the recorded data in a valid way. The model's effectiveness in describing the data was assessed by means of the goodness of fit test (chi square deviance) and analysis of residuals (19). Weighting factors were not used during the multivariate analysis, as no attempt was being made to obtain national averages.

\section{RESULTS}

ENDESA-91 collected breast-feeding data on 4699 children. Of these, 
504 were excluded from the current study because they were over 5 years of age, and an additional 95 were excluded because their age data were not reliable. Of the remaining children, only the last live-born child of each mother was selected. This process reduced the study sample to 2714 mother-child pairs.

Most of the mothers in the study sample were under age 30 and had three children or fewer (Table 2). Only $9 \%$ had never received any formal education, but $55 \%$ had gone only as far as primary school. Over $60 \%$ of the children were less than 3 years old, and $60 \%$ were from urban areas. About a third of the mothers said they were engaged in salaried employment at the time their most recent child was born. Weighted percentages were similar to unweighted percentages.

Of the 2714 study children, 187 $(6.9 \%)$ were never breast-fed $(95 \% \mathrm{CI}$ : $5.7 \%-7.9 \%$ ). Most of the mothers who did not initiate breast-feeding made that decision because the child rejected the breast $(33.9 \%)$ or because she (the mother) had insufficient milk (30.0\%). The unadjusted risk of not breastfeeding was smallest $(4.8 \%)$ in mothers 25-29 years old, reaching its maximum levels of $8.3 \%$ and $8.5 \%$ in very young and old mothers, respectively (Table 3). In addition, the risk of not breastfeeding was found to increase with increasing education and socioeconomic status, and to be higher among

TABLE 2. Absolute and percentage distribution of the study population, by sociodemographic characteristics; Dominican Republic, 1991

\begin{tabular}{|c|c|c|c|c|}
\hline $\begin{array}{l}\text { Sociodemographic } \\
\text { variable }\end{array}$ & $n^{\mathrm{a}}$ & $\%$ & $\begin{array}{c}\text { Cumulative } \\
\%\end{array}$ & $\begin{array}{c}\text { Weighted } \\
\% \%^{b}\end{array}$ \\
\hline \multicolumn{5}{|l|}{ Mother's age in years: } \\
\hline$\leq 19$ & 424 & 15.6 & 15.6 & 13.6 \\
\hline $20-24$ & 925 & 34.1 & 49.7 & 32.9 \\
\hline $25-29$ & 714 & 26.3 & 76.0 & 27.9 \\
\hline $30-34$ & 418 & 15.4 & 91.4 & 17.1 \\
\hline $35-39$ & 173 & 6.4 & 97.8 & 6.4 \\
\hline $40-49$ & 59 & 2.2 & 100.0 & 1.9 \\
\hline \multicolumn{5}{|l|}{ Maternal parity: } \\
\hline 1 (primipara) & 738 & 27.2 & 27.2 & 28.6 \\
\hline 2 & 652 & 24.0 & 51.2 & 23.1 \\
\hline 3 & 564 & 20.8 & 72.0 & 22.2 \\
\hline 4 & 295 & 10.9 & 82.9 & 10.4 \\
\hline$\geq 5$ & 465 & 17.1 & 100.0 & 15.8 \\
\hline \multicolumn{5}{|l|}{ Formal education: } \\
\hline None & 244 & 9.0 & 9.0 & 8.0 \\
\hline Primary & 1493 & 55.0 & 64.0 & 52.0 \\
\hline Secondary & 705 & 26.0 & 90.0 & 28.0 \\
\hline University & 272 & 10.0 & 100.0 & 12.0 \\
\hline \multicolumn{5}{|l|}{ Child's age in years: } \\
\hline 0 & 886 & 32.6 & 32.6 & 31.3 \\
\hline 1 & 778 & 28.7 & 61.3 & 28.6 \\
\hline 2 & 460 & 17.0 & 78.3 & 17.1 \\
\hline 3 & 327 & 12.0 & 90.3 & 12.8 \\
\hline 4 & 263 & 9.7 & 100.0 & 10.1 \\
\hline \multicolumn{5}{|l|}{ Area of residence: } \\
\hline Urban & 1632 & 60.1 & 60.1 & 62.1 \\
\hline Rural & 1082 & 39.9 & 100.0 & 37.9 \\
\hline \multicolumn{5}{|l|}{$\begin{array}{l}\text { Mother's employment } \\
\text { status: }\end{array}$} \\
\hline Not working & 1827 & 67.3 & 67.3 & 64.8 \\
\hline Working & 839 & 32.7 & 100.0 & 35.2 \\
\hline
\end{tabular}

a Differences between the totals for different variables reflect study pairs for which no information was available.

b Distribution weighted in accordance with the mother's probability of selection.

urban residents. On the other hand, the risk decreased with increasing parity, appeared unaffected by the mother's employment status, and was not significantly affected by the child's age at the time of the survey. (This latter finding suggests that there were no significant changes in the frequency of initiation of breast-feeding over the five years preceding the survey.)

With regard to care during pregnancy and childbirth, the risk of not initiating breast-feeding was found to be independent of the number of prenatal checkups; but mothers whose prenatal examinations were performed by nurses had a $46 \%$ greater probability of not initiating breastfeeding than mothers seen by physicians (Table 4). However, the risk of not initiating breast-feeding was more than twice as great among mothers whose care during delivery was provided by a general practitioner as opposed to a nurse, and among those whose delivery care was provided by an obstetrician the risk was 3.4 times as great. The risk of not initiating breast-feeding was also greater for study mothers who delivered at private institutions $(9.8 \%)$ and public institutions (5.8\%), as compared to those who gave birth at home (2.9\%).

Mothers who had a major illness during pregnancy, ${ }^{4}$ those who gave birth by cesarian section, and those who gave birth to children with low birthweights experienced considerably greater risks of not initiating breast-feeding than did mothers with apparently normal pregnancies (Table 5). However, the likelihood of not initiating breast-feeding was found to be independent of the sex of the child.

Application of the final logistic regression model indicated that of all of the study variables, the only ones having independent effects on the risk of not initiating breast-feeding were major illness during pregnancy, delivery of a low birthweight infant, never 
TABLE 3. Numbers and percentages of study mothers not initiating breast-feeding, and odds ratios $(\psi)$ for failure to initiate breast-feeding with their respective $95 \%$ confidence intervals, for each of the sociodemographic variables listed in Tables 1 and 2

\begin{tabular}{|c|c|c|c|c|c|}
\hline \multirow[b]{2}{*}{ Sociodemographic variable } & \multirow[b]{2}{*}{ Total $^{a}$} & \multicolumn{2}{|c|}{$\begin{array}{l}\text { Mothers who did } \\
\text { not initiate } \\
\text { breast-feeding }\end{array}$} & \multirow{2}{*}{$\begin{array}{c}\psi \\
\text { (unadjusted) }\end{array}$} & \multirow{2}{*}{$\begin{array}{l}95 \% \mathrm{Cl} \\
\text { for } \psi\end{array}$} \\
\hline & & $n$ & $\%$ & & \\
\hline \multicolumn{6}{|l|}{ Mother's age in years: } \\
\hline$\leq 19$ & 424 & 35 & 8.3 & 1.0 & - \\
\hline $20-24$ & 925 & 73 & 7.9 & 0.9 & $0.6-1.5$ \\
\hline $25-29$ & 714 & 34 & 4.8 & 0.6 & $0.3-0.9$ \\
\hline $30-34$ & 418 & 27 & 6.5 & 0.8 & $0.4-1.3$ \\
\hline $35-39$ & 173 & 12 & 6.9 & 0.8 & $0.4-1.7$ \\
\hline $40-49$ & 59 & 5 & 8.5 & 1.0 & $0.3-2.9$ \\
\hline \multicolumn{6}{|l|}{ Maternal parity: } \\
\hline 1 (primipara) & 738 & 77 & 10.4 & 2.7 & $1.6-4.7$ \\
\hline 2 & 652 & 40 & 6.1 & 1.5 & $0.8-2.8$ \\
\hline 3 & 564 & 36 & 6.4 & 1.6 & $0.9-2.9$ \\
\hline 4 & 295 & 14 & 4.7 & 1.2 & $0.5-2.5$ \\
\hline$\geq 5$ & 465 & 19 & 4.1 & 1.0 & - \\
\hline \multicolumn{6}{|l|}{ Formal education: } \\
\hline None/primary & 1737 & 100 & 5.8 & 1.0 & - \\
\hline Secondary & 705 & 55 & 7.8 & 1.4 & $1.0-2.0$ \\
\hline University & 272 & 31 & 11.4 & 2.1 & $1.3-3.3$ \\
\hline \multicolumn{6}{|l|}{ Child's age in years: } \\
\hline 0 & 886 & 58 & 6.5 & 1.0 & $0.6-1.8$ \\
\hline 1 & 778 & 50 & 6.4 & 1.0 & $0.5-1.8$ \\
\hline 2 & 460 & 32 & 7.0 & 1.1 & $0.6-2.1$ \\
\hline 3 & 327 & 29 & 8.9 & 1.4 & $0.7-2.7$ \\
\hline 4 & 263 & 17 & 6.5 & 1.0 & - \\
\hline \multicolumn{6}{|l|}{ Socioeconomic level: } \\
\hline Low & 987 & 44 & 4.5 & 1.0 & - \\
\hline Medium & 925 & 64 & 6.9 & 1.6 & $1.0-2.4$ \\
\hline High & 793 & 78 & 9.8 & 2.3 & $1.6-3.5$ \\
\hline \multicolumn{6}{|l|}{ Area of residence: } \\
\hline Rural & 1082 & 56 & 5.2 & 1.0 & - \\
\hline Urban & 1632 & 130 & 8.0 & 1.6 & $1.1-2.2$ \\
\hline \multicolumn{6}{|l|}{ Mother's employment status: } \\
\hline Not working & 1827 & 128 & 7.0 & 1.0 & - \\
\hline Working & 839 & 57 & 6.8 & 1.0 & $0.7-1.3$ \\
\hline
\end{tabular}

${ }^{a}$ Differences between the totals for different variables reflect study pairs for which no information was available.

having delivered previously, and an intermediate or high (as opposed to low) socioeconomic level (Table 6).

Of all these variables, low birthweight was found to be the one most strongly associated with the risk of not initiating breast-feeding (Table 6). Children with low birthweight $(<2500 \mathrm{~g})$ were almost three times more likely not to have been breast-fed than children with higher birth-weights. In addition, $45.8 \%$ of the mothers failing to breast-feed low birthweight children said they did not breast-feed because the child was ill, as compared to only $8.1 \%$ of the mothers who did not breast-feed a child of adequate birthweight.

Mothers with major illnesses during pregnancy had a risk of not initiating breast-feeding that was more than twice as great as that of mothers with no apparent illness during pregnancy (see Table 6). This result did not change when 81 mothers $(3 \%$ of the sample) who received no prenatal checkups were excluded. With regard to parity, it was found that the risk of not initiating breast-feeding was almost twice as great among primi- paras (mothers delivering for the first time) as it was among multiparas.

Finally, income level was found to be strongly associated with failure to initiate breast-feeding. As compared to low-income mothers, mothers in the intermediate or (especially) high income groups had a risk of not initiating breast-feeding that was considerably greater (see Table 6).

When income level was taken into consideration, the aforementioned significant effects of medical care (see Table 4) upon the risk of not initiating breast-feeding disappeared. Similarly, when the presence of illness during pregnancy, low birthweight, and parity were taken into account, it was found that the type of personnel conducting the prenatal exams no longer significantly influenced the risk of not initiating breast-feeding.

According to the results of the goodness of fit test and the analysis of residuals (19), the regression model obtained appropriately described the data observed (adjusted $\chi^{2}$ for the model $=24.0$, with $17 \mathrm{df} ; P=0.12$ ), and these results were not due to the presence of observations that excessively influenced the final model.

\section{DISCUSSION}

Some of the study's characteristics could have biased the results obtained. Since only $78 \%$ of all of the women selected participated in the original survey (13), some type of selection bias is possible; that is, initiation and duration of breast-feeding could be associated with participation in the study. Unfortunately, there is no information available that would make it possible to evaluate the direction and magnitude of such a potential bias (13). However, the bias resulting from using a sample of survivors in the present study should be minimal, as mortality among women of reproductive age is relatively rare.

Another possible source of error was the absence of data on potential confounding factors, such as the roomingin behavior of the mother with the newborn child (21), the father's prefer- 
TABLE 4. Numbers and percentages of study mothers not initiating breast-feeding, and odds ratios $(\psi)$ for failure to initiate breast-feeding with their respective $95 \%$ confidence intervals, for each of the medical care variables listed in Table 1

\begin{tabular}{|c|c|c|c|c|c|}
\hline \multirow[b]{2}{*}{ Medical care variable } & \multirow[b]{2}{*}{ Total $^{a}$} & \multicolumn{2}{|c|}{$\begin{array}{l}\text { Mothers who did } \\
\text { not initiate } \\
\text { breast-feeding }\end{array}$} & \multirow{2}{*}{$\begin{array}{c}\psi \\
\text { (unadjusted) }\end{array}$} & \multirow{2}{*}{$\begin{array}{c}95 \% \mathrm{Cl} \\
\text { for } \psi\end{array}$} \\
\hline & & $n$ & $\%$ & & \\
\hline \multicolumn{6}{|l|}{ No. of prenatal checkups: } \\
\hline $0-4$ & 669 & 43 & 6.4 & 1.0 & - \\
\hline $5-7$ & 874 & 54 & 6.2 & 1.0 & $0.6-1.4$ \\
\hline $8-9$ & 674 & 55 & 8.2 & 1.3 & $0.9-1.9$ \\
\hline$\geq 10$ & 485 & 32 & 6.6 & 1.0 & $0.7-1.6$ \\
\hline \multicolumn{6}{|c|}{ Prenatal checkups performed by: } \\
\hline Physician & 1360 & 77 & 5.7 & 1.0 & - \\
\hline Nurse & 1256 & 104 & 8.3 & 1.5 & $1.1-1.9$ \\
\hline Other & 97 & 4 & 4.1 & 0.7 & $0.3-1.9$ \\
\hline \multicolumn{6}{|c|}{ Care during delivery provided by: } \\
\hline Nurse & 201 & 5 & 2.5 & 1.0 & - \\
\hline General practitioner & 1056 & 58 & 5.5 & 2.2 & $0.9-5.4$ \\
\hline Obstetrician & 1300 & 112 & 8.6 & 3.5 & $1.4-8.4$ \\
\hline \multicolumn{6}{|l|}{ Place of delivery: } \\
\hline Home/other & 205 & 6 & 2.9 & 1.0 & - \\
\hline Public facility & 1666 & 97 & 5.8 & 2.0 & $0.9-4.5$ \\
\hline Private facility & 843 & 83 & 9.8 & 3.4 & $1.5-7.6$ \\
\hline
\end{tabular}

a Differences between the totals for different variables reflect study pairs for which no information was available.

TABLE 5. Numbers and percentages of study mothers not initiating breast-feeding, and odds ratios $(\psi)$ for failure to initiate breast-feeding with their respective $95 \%$ confidence intervals, for each of the variables related to pregnancy or the child listed in Table 1 (no significant change results if the $\mathbf{8 1}$ mothers who had no prenatal checkups are excluded)

\begin{tabular}{|c|c|c|c|c|c|}
\hline \multirow{2}{*}{$\begin{array}{l}\text { Variables relating to } \\
\text { pregnancy or the child }\end{array}$} & \multirow[b]{2}{*}{ Total $^{\mathrm{a}}$} & \multicolumn{2}{|c|}{$\begin{array}{l}\text { Mothers who did } \\
\text { not initiate } \\
\text { breast-feeding }\end{array}$} & \multirow{2}{*}{$\begin{array}{c}\psi \\
\text { (unadjusted) }\end{array}$} & \multirow{2}{*}{$\begin{array}{l}95 \% \mathrm{Cl} \\
\quad \text { for } \psi\end{array}$} \\
\hline & & $n$ & $\%$ & & \\
\hline \multicolumn{6}{|l|}{ Illness during pregnancy: ${ }^{b}$} \\
\hline No & 2320 & 134 & 5.8 & 1.0 & - \\
\hline Yes & 392 & 52 & 13.3 & 2.3 & $1.7-3.1$ \\
\hline \multicolumn{6}{|l|}{ Type of delivery: } \\
\hline Natural & 2098 & 129 & 6.1 & 1.0 & - \\
\hline Cesarian & 606 & 55 & 9.1 & 1.5 & $1.1-2.0$ \\
\hline \multicolumn{6}{|l|}{ Child's birthweight: } \\
\hline$\geq 2500 \mathrm{~g}$ & 2320 & 134 & 5.8 & 1.0 & - \\
\hline$<2500 \mathrm{~g}$ & 231 & 35 & 15.2 & 2.6 & $1.8-3.7$ \\
\hline \multicolumn{6}{|l|}{ Sex of the neonate: } \\
\hline Female & 1312 & 83 & 6.3 & 1.0 & - \\
\hline Male & 1402 & 103 & 7.3 & 1.2 & $0.9-1.5$ \\
\hline
\end{tabular}

aifferences between the totals for different variables reflect study pairs for which no information was available.

${ }^{b}$ Risk of miscarriage, vaginal hemorrhage, placenta previa, high blood pressure, cardiopathy, diabetes, kidney disease, liver disease, tuberculosis, or tumors.

ence for breast or bottle feeding (22), breast-feeding education received during pregnancy (23), and obesity (24). However, it is reasonable to expect that the confounding effect of such variables has been partially controlled by including income level and place of delivery in the multivariate analysis.
Finally, despite the fact that the quality of the data generated by the demographic and health surveys has been substantiated in a number of studies $(25,26)$, the validity of maternal reporting of illnesses during pregnancy does not appear to have been evaluated.

In the current study, $93 \%$ of the mothers reported having initiated breast-feeding. Despite the fact that it came from a different sample, this figure was only slightly lower than that reported by Ogando et al. (27) in a cohort study conducted on a sample of mothers from various cities in the Dominican Republic who gave birth at public hospitals.

The frequency of initiation of breastfeeding was found to be slightly greater in rural than in urban areas (95\% versus $92 \%)$. Investigators in other developing countries have recorded high levels of initiation of breast-feeding in urban areas (28), while frequently recording even higher levels in rural areas (29).

Our results, like those obtained by Ogando et al. (27), suggest that the study population's frequency of initiation of breast-feeding has remained stable over the past 5 years. This finding differs from the conclusion reached by Velzeboer et al. (15), whose informal review of secondary sources found a decline in the initiation of breast-feeding among poor urban population groups in recent years, combined with an increase among middleand high-income groups.

The presence of illnesses during pregnancy, low birthweight, parity, and socioeconomic status were the only variables independently associated with the risk of not initiating breast-feeding. Although it could be the result of information errors, the observed increase in the risk of failing to initiate breast-feeding among mothers with illnesses during pregnancy is consistent with the findings reported by Mata et al. (30) among Costa Rican mothers. This increased risk could be caused by the fact that mothers with illnesses during pregnancy, whether because of their own illness or because of problems occurring in the neonate, 
TABLE 6. Factors found to significantly affect initiation of breast-feeding in the study population after adjusting for other variables, showing odds ratios $(\psi)$ for not initiating breastfeeding with their corresponding $95 \%$ confidence intervals

\begin{tabular}{|c|c|c|c|}
\hline Characteristic & $\psi$ & $95 \% \mathrm{Cl}$ & $P$ \\
\hline \multicolumn{4}{|c|}{ Illness during pregnancy: ${ }^{\mathrm{a}}$} \\
\hline No & 1.0 & - & - \\
\hline Yes & 2.3 & $1.6-3.2$ & $<0.001$ \\
\hline \multicolumn{4}{|l|}{ Low birthweight: } \\
\hline No & 1.0 & - & - \\
\hline Yes $^{b}$ & 2.9 & $1.9-4.4$ & $<0.001$ \\
\hline \multicolumn{4}{|l|}{ Maternal parity: } \\
\hline Multiparas & 1.0 & - & - \\
\hline Primiparas & 1.9 & $1.4-2.7$ & $<0.001$ \\
\hline \multicolumn{4}{|l|}{ Socioeconomic level: } \\
\hline Low & 1.0 & - & - \\
\hline Medium & 1.7 & $1.1-2.4$ & 0.023 \\
\hline High & 2.1 & $1.4-3.1$ & $<0.001$ \\
\hline
\end{tabular}

are more frequently separated from their children during the perinatal period-a circumstance that constrains initiation of breast-feeding (31). It is also possible that some pregnancyrelated illnesses are associated, by means of hormonal mechanisms, with reduced production of breast milk, which likewise hinders initiation of breast-feeding.

Mothers delivering low birthweight children failed to initiate breast-feeding at almost three times the rate of mothers delivering children with adequate birthweights. Similar findings have been reported from other studies $(32,33)$. Winikoff et al. (28) have reported a greater risk of failure to initiate breast-feeding among mothers whose children experienced problems in the immediate perinatal period. The lower rate of initiation of breast-feeding among mothers of low birthweight children could be mediated by mother-child separation during the first few days following childbirth (31), as well as by the low birthweight child's inability to suck with sufficient strength to stimulate breast milk production. This argument is supported by the fact that mothers who failed to initiate breast-feeding of low birthweight children reported that illness of the child caused this fail- ure with far greater frequency than mothers who failed to initiate breastfeeding of children with adequate birthweights.

In the current study, the risk of not initiating breast-feeding was almost twice as great among primiparas as it was among multiparas. The results of a study conducted in Puerto Rico (34) also point to primiparas experiencing a greater risk of failure to initiate breast-feeding. However, other studies (28) have found no association between parity and initiation of breast-feeding, probably due to the high frequency of breast-feeding involved. The lower frequency of initiation of breast-feeding among primiparas could be associated with lack of awareness of its benefits.

The increase in the risk of not initiating breast-feeding as income level increases has also been reported in other studies $(28,35,36)$, despite the use of different definitions for this variable. Interpretation of this finding is complex, as income level is a variable associated with other factors that are harder to measure, such as sociocultural beliefs and values (37).

Various authors $(28,30,34)$ have concurred in pointing out the adverse effects of "industrialization" and "westernization of lifestyles" upon the initia- tion and duration of breast-feeding. These effects appear to be mediated by introduction and aggressive marketing of breast milk substitutes, introduction of new technologies and practices in maternity and perinatal care wards, and a change in attitudes and beliefs with regard to breast-feeding. The adverse effects may be greatest among social groups having the greatest purchasing power and the greatest access to medical care and westernized education. The changes occurring in the initiation of breast-feeding in the population of Puerto Rico from 1946 to 1982 (34) are a good example of these effects of westernization.

The lack of association between maternal employment status and initiation of breast-feeding observed in this study has been previously reported by Gómez et al. (14) and Johnson (38) in Dominican women, as well as by other authors in other developing countries (28). This finding for Dominican women is not surprising, since by law they are entitled to 3 months of paid postpartum leave. In addition, only $31 \%$ of the mothers in this study were engaged in salaried employment, and of these half normally took their child with them to work.

Maternal age did not appear to influence initiation of breast-feeding. In three of four studies conducted in developing countries (28) there was likewise no association found between maternal age and failure to breast-feed. In the only study where a significant association was detected (31), the frequency of initiation of breast-feeding decreased with the age of the mother.

As noted above, the fact that maternal education and medical care characteristics were not found to influence the rate of breast-feeding in this study may be explained by inclusion in the regression model of income level and the presence of illness during pregnancy.

Although initiation of breast-feeding was very frequent and does not appear to have decreased in recent years, in other countries a downward trend associated with economic growth has been observed $(11,34)$. Consequently, it would be advisable to implement 
activities aimed at preventing a drop in the frequency of initiation of breastfeeding among Dominican women.

In a review of studies conducted to assess breast-feeding promotion programs, Tognetti (29) has pointed out that in most such programs no consideration has been given to factors that might help define those groups at which the program is primarily the control of diarrhoeal diseases among young children: promotion of breast-feeding. Bull World Health Organ 1984;62:271-291.

2. Mahalanabis D, Alam AN, Rahman N, Hasnat A. Prognostic indicators and risk factors for increased duration of acute diarrhoea and for persistent diarrhoea in children. Int I Epidemiol 1991;20:1064-1072.

3. Forman MR, Graubard BI, Hoffman HJ, Beren $R$, Harley EE, Bennet P. The Pima infant feeding study: breast-feeding and respiratory infections during the first year of life. Int I Epidemiol 1984;13:447-453.

4. Victoria CG, Smith PG, Vaughan JP, et al. Evidence for protection by breast-feeding against infant deaths from infectious diseases in Brazil. Lancet 1987;2:319-322.

5. Butte NF, Garza C, Smith EO, Nichols BL. Human milk intake and growth in exclusively breast-fed infants. I Pediatr 1984;104:187-195.

6. Short RV, Lewis PR, Renfree MB, Shaw G. Contraceptive effects of extended lactational amenorrhoea: beyond the Bellagio Consensus. Lancet 1991;337:715-717.

7. Huffman SL. Determinants of breast-feeding in developing countries: overview and policy implications. Stud Fam Plann 1984;15:170-183.

8. Pérez Escamilla R. Breast-feeding in Africa and the Latin American and Caribbean region: the potential role of urbanization. $J$ Trop Pediatr 1994;40:137-143.

9. Forman MR. Review of research on the factors associated with choice and duration of infant feeding in less-developed countries. Pediatrics 1984;74(4,pt 2):667-694.

10. Winikoff B, Laukaran VH. Breast feeding and bottle feeding controversies in the developing world: evidence from a study in four countries. Soc Sci Med 1989;29:859-868.

11. Division of Family Health, World Health Organization. The prevalence and duration of breast-feeding: critical review of available information. World Health Stat Q 1982;35: 92-112.

12. Secretaría de Estado de Salud Pública y Asistencia Social, Consejo Nacional de Población y Familia, Institute for Resource Development/Westinghouse. Encuesta demográfica y de salud 1986 (DHS-86). Santo Domingo: CONAPOFA; 1987:21-24.

13. Instituto de Estudios de Población y Desarrollo, Oficina Nacional de Planificación, IRD/ Macro International Inc. Encuesta Demográfica y de Salud 1991. Santo Domingo: PROFAMILIA; 1992:131-146. directed, despite the fact that this is critical to the intervention's success.

At present, the Dominican Republic's National Breast-feeding Program (15) is focused on users of the public health system. Although it is possible to argue that the effects of failure to breast-feed might be more harmful in this group, the results of the current study show that primiparous women

\section{REFERENCES}

14. Gómez E, Montero R, Canario M. Patrones de lactancia materna en el Distrito Nacional de la República Dominicana. In: CENISMI. Estado actual de la lactancia materna en la República Dominicana. Santo Domingo: CENISMI; 1987:5-15.

15. Velzeboer M, Coen J, Alas de Chávez A, Fischer M. El estado de la lactancia materna en la República Dominicana: prácticas y promoción. Washington, DC: United States Agency for International Development, MotherCare, LAC Health, and Nutrition Sustainability; 1992:1-112.

16. Sullivan JM. The collection of mortality data in WFS and DHS surveys. In: Vallin J, D'Souza S, Palloni A. Measurement and analysis of mortality: new approaches. Oxford: Clarendon Press; 1990:48-63.

17. Bautista LE. "Razón relativa" y "tasa relativa" como traducciones de odds ratio y hazard ratio (letter). Bol Oficina Sanit Panam 1995;119: 278-279.

18. Cornfield J. A statistical problem arising from retrospective studies. In: Neyman J. Proceedings of the Third Berkeley Symposium. Berkeley: University of California Press; 1956:134-148.

19. Hosmer DW, Lemeshow S. Applied logistic regression. New York: Wiley; 1989.

20. Greenland S. Modeling and variable selection in epidemiologic analysis. Am J Public Health 1989;79:340-349.

21. Pérez Escamilla R, Segura Millán S, Pollitt E, Dewey KG. Effect of the maternity ward system on the lactation success of low-income urban Mexican women. Early Hum Dev 1992; 31:25-40.

22. Jones DA. The choice to breast feed or bottle feed and influences upon that choice: a survey of 1525 mothers. Child Care Health Dev 1987; 13:75-85.

23. Winikoff B, Castle MA. The influence of health services on infant feeding. In: Winikoff B, Castle MA, Laukaran VH. Feeding infants in four societies: causes and consequences of mothers' choices. New York: Greenwood; 1988:147-164.

24. Rutishauser IH, Carlin JB. Body mass index and duration of breast feeding: a survival analysis during the first six months of life. J Epidemiol Community Health 1992;46:559-565.

25. Goldman N, Rutstein SO, Singh S. Assessment of the quality of data in 41 WFS surveys: a comparative approach. Voorburg, The Netherlands: International Statistics Institute; 1985:5-83.

26. Eaton Evans J, Dugdale AE. Recall by mothers of the birth weights and feeding of their children. Hum Nutr Appl Nutr 1986;40:171-175. (and perhaps ones with few deliveries), women who have major illnesses during pregnancy, women delivering children with low birthweights, and women with high income levels constitute groups toward which activities aimed at promoting the initiation of breast-feeding should be specifically directed.
27. Ogando E, Romero H, Soriano G. Monitoreo del efecto de las políticas económicas y sociales en el bienestar infantil 1988-1991. Santo Domingo: Centro Nacional de Investigación en Salud Materno-Infantil, Oficina Nacional de Planificación, UNICEF; 1992:136.

28. Winikoff B. Summary. In: Winikoff B, Castle MA, Laukaran VH. Feeding infants in four societies: causes and consequences of mothers' choices. New York: Greenwood; 1988:227-246.

29. Tognetti J. Evaluating breast-feeding promotion programmes. In: Jelliffe DB, Jelliffe EFP. Programmes to promote breast-feeding. New York: Oxford University Press; 1988:405-419.

30. Mata L, Sáenz P, Araya JR, Allen MA, García ME, Rodríguez ME, et al. Promotion of breastfeeding in Costa Rica: the Puriscal study. In: Jelliffe DB, Jelliffe EFP. Programmes to promote breast-feeding. New York: Oxford University Press; 1988:55-69.

31. Winikoff B, Durongdej S, Cerf BJ. Infant feeding in Bangkok, Thailand. In: Winikoff B, Castel MA, Laukaran VH. Feeding infants in four societies: causes and consequences of mothers' choices. New York: Greenwood; 1988:15-41.

32. Xavier CC, Jorge SM, Gonçalves AL. Prevalencia do aleitamento materno em recemnascidos de baixo peso. Rev Saude Publica 1991;25:381-387.

33. Ever-Hadani P, Seidman DS, Manor O, Harlap S. Breast-feeding in Israel: maternal factors associated with choice and duration. J Epidemiol Community Health 1994:48:281-285.

34. Becerra JE, Smith JC. Breast-feeding patterns in Puerto Rico. Am J Public Health 1990;80: 694-697.

35. Manderson L. "These are modern times:" infant feeding practice in Peninsular Malaysia. Soc Sci Med 1984;18:47-57.

36. Grossman LK, Fitzsimmons SM, Larsen Alexander JB, Sachs L, Harter C. The infant feeding decision in low and upper income women. Clin Pediatr (Philadelphia) 1990; 29:30-37.

37. Liberatos P, Link BG, Kelsey JL. The measurement of social class in epidemiology. Epidemiol Rev 1988;10:87-121.

38. Johnson C. Nutritional status in the Dominican Republic. Santo Domingo: Tufts University School of Nutrition/USAID; 1987

Manuscript received on 30 March 1996. Revised version accepted for publication on 9 October 1996 
RESUMEN Las relaciones entre el inicio del amamantamiento y sus determinantes varían en distintas poblaciones, pero su conocimiento es fundamental para orientar los programas de promoción de la lactancia materna. Los datos de la Encuesta Demográfica y de

Factores asociados al inicio de la lactancia materna en mujeres dominicanas
Salud de 1991 de la República Dominicana se usaron para identificar factores asociados con el inicio del amamantamiento en una muestra aleatoria de mujeres en edad fértil. Aproximadamente 93\% de 2714 madres informaron haber iniciado el amamantamiento en su último niño nacido vivo menor de 5 años y no hubo cambios importantes en este porcentaje en los últimos 5 años. Se realizó un análisis de regresión logística mediante el cual se calcularon valores de la razón de posibilidades (odds ratio $(\psi)$, en inglés) como medidas de asociación. Las madres que tuvieron alguna enfermedad durante el embarazo $(\psi=2,3)$, las que tuvieron niños con bajo peso al nacer $(\psi=$ $2,9)$, las primíparas $(\psi=1,9)$ y las de nivel de ingresos medio $(\psi=1,6)$ y alto $(\psi=2,1)$ tuvieron un riesgo significativamente mayor de no iniciar el amamantamiento. Estas mujeres deberían constituir grupos prioritarios en los programas de promoción de la lactancia materna.

\section{ERRATA}

Rigau-Pérez y Asociación de Epidemiólogos de Puerto Rico, "Manifestaciones clínicas del dengue hemorrágico en Puerto Rico, 1990-1991"

(Rev Panam Salud Publica/Pan Am J Public Health 1997;1(6):435-443)

Se llama la atención de los lectores a algunos errores tipográficos y de interpretación en la versión española de "Clinical manifestations of dengue hemorrhagic fever in Puerto Rico, 1990-1991", trabajo publicado en nuestro número de mayo (1997;1(5):381). Estos errores, que aquí se detallan, son enteramente responsabilidad de nuestra redacción.

- En español la Puerto Rican Association of Epidemiologists, entidad coautora del trabajo, se llama Asociación de Epidemiólogas y Epidemiólogos de Puerto Rico.

- P. 436, 3. ${ }^{a}$ columna, final del 2. ${ }^{\circ}$ párrafo: Debe decir "Los casos identificados por medio del algoritmo fueron seleccionados para la revisión de sus registros hospitalarios, labor efectuada por uno de los autores (JGRP)".

- P. 437, final de la 2. a columna e inicio de la 3. a: Debe decir "Estos casos se consideraron solo probables porque los pacientes..."

- P. 439, 1. a columna, líneas 24-26: Debe decir “. . . solo cuatro egresaron con un diagnóstico de $\mathrm{DH}$ ".

- P. 440, 3. a columna, línea 10: Debe decir "Esa alta tasa de letalidad (3/53 ó 5,7\%) en pacientes con FD sugiere que en dicho grupo ..."

- P. 440, 3. ${ }^{a}$ columna, líneas 25-29 del segundo párrafo: Debe decir “. . donde hay amplia disponibilidad de pruebas químicas y microscópicas automatizadas para la detección de hematuria y donde la prueba del torniquete se aplica con poca frecuencia". 